\title{
BENCE Erika
}

Újvidéki Egyetem, Bölcsészettudományi Kar

Magyar Nyelv és Irodalom Tanszék

Újvidék, Szerbia

erika.bence@fff.uns.ac.rs

\section{REFERENCIÁLIS ÉS FIKTÍV MEZEI MÁRK UTOLSÓ SZOMBAT CÍMÜ REGÉNYÉBEN ${ }^{1}$}

\section{Referential and Fictional Features in Márk Mezei's Novel Utolsó Szombat (The Last Saturday) \\ Referencijalno i fiktivno u romanu Marka Mezeija Utolsó szombat (Poslednja subota)}

Mezei Márk Utolsó szombat címü regényének cselekménye valóságos térben és időben, meglehetősen szük keretek között játszódik: 1944. január 14-én, a budapesti Nagyatádi Szabó utca 32-es szám alatti lepusztult bérházban. Egyik szereplője, Áháron Rokéách belzi rabbi történelmi személyiség: ismertek életének referenciális vonatkozásai. A másik főszereplö, Adler Magda, fiktív személy - az ortodox zsidó vallási vezetővel ellentétben - asszimiláns családból származik, nem ismeri saját vallási hagyományait, biszexuális és alkoholista. Mindketten a lebukástól és a megsemmisüléstől való félelem kiváltotta szélsőséges magány állapotába kerülnek: a rabbi elhagyva a közösséget és hittársait árulóvá válik, míg Magda szerelmi árulás áldozatává lesz. Azonos léthelyzetbe, egymástól néhány méternyi közelségbe kerülnek: a félelem érzete azonban áthatolhatatlan falat von közéjük. Sohasem találkoznak. A dolgozat a narratíva motivikus és tropológiai vizsgálatára vállalkozik.

Kulcsszavak: fiktív, referenciális, test, lélek, motívumok, toposzok

\footnotetext{
1 A tanulmány a Szerb Köztársaság Oktatás- és Tudományügyi Minisztériuma 178017. számú projektuma keretében készült.
} 


\section{Bevezetés}

Mezei Márk Utolsó szombat (2018) címü regénye, amikor egyik elbeszélésszála az Áháron Rokéách ${ }^{2}$ (1880-1957) belzi rabbihoz köthető 1943-1944-es budapesti eseményeket tematizálja, olyan fontos narratopoétikai kérdéseket is aktualizál, mint például a történeti narratíva létformájáról és müködési elveiről alkotott nézetek, a referenciális és a fiktív viszonyrendszerének jelentésalkotó szerepe a műfajok életében, illetve a (már klasszikusnak számító) markiewiczi értelemben vett „pszeudo-hős”, a „pszeudo-valóságos alakmás” (Markiewicz 1968, 323-324) müfajkonstrukciós elemként való értelmezése. Mindezt ellentétében is tükrözteti: a történelmi személyiséghez füződő történéseket és jelentéseket egy fiktív, kitalált alak, Adler Magda életében. Az elbeszélés azonban nem csak ezzel feszíti szét a hagyományos értelemben vett történeti narratíva kereteit, hiszen arra mindig (pontosabban a Walter Scott-i, sőt, a novalisi típusú történelmi regény hatáskorszakának végéig) jellemző volt a fiktív (az elbeszélés elöterében álló) hős ${ }^{3}$ szerepeltetése.

A hagyományos és a (poszt)modern irodalomtudomány egyaránt támpontokat nyújt a jelenség értelmezéséhez. Ismert monográfiájában Lukács György a történelemnek az emberek sorsában való tükröződéséről, a történelmi regénynek nevezett narratíva alakjainak ,végigvitt történelmi pszichológiájá”-ról mint fontos müfajalkotó momentumról beszél (Lukács 1977, 86), Northrop Frye „pszichológiai archetípusok”-at (Frye 1998, 263) azonosít a múlt elbeszélésének konstrukcióiban. Gyáni Gábor a vonatkozó elméletek összecsengő

2 Áháron Rokéách (1880-1957) nevének írásmódja eltérő. A regényben: Áron Rokeáh. Egyes forrásokban Áháron Rokeách (Borsányi Schmidt 2006), másutt Reb Áron Rokéách (Freimovics 1998), de találkozhatunk az Áháron Rokéách (Raj 2015) írásmóddal is. A dolgozat az Áháron Rokéách változatot alkalmazza, kivéve a regényből származó idézetekben. Az ok: a történetben ugyancsak szereplő fivér, Rabbi Mordecháj Rokéách nevével való egyeztetés.

3 Erről az eljárásról, vagyis a valós személyeknek a fikcióban való „visszafogott”, a háttértörténetben való szerepeltetéséről mondja Roland Barthes:

Éppen e csekély jelentőség az, ami a történelmi személynek mint szereplőnek a valóságosság pontos súlyát megadja. [...] Ha pusztán elvegyülnek fiktív társaik szomszédságában, ha csak utalás történik rájuk valamely társas összejövetel kapcsán, e mértékletesség, mint valami zsilip, mely kiegyenlíti a víz két különböző szintjét, egy szintbe hozza a regényt és a történelmet" (Barthes 1997, 133-134).

Márton László Novalis Heinrich von Ofterdingen (1802) című mủvének fordítói jegyzetében e kérdésről úgy véli, a regény címszereplője „valóban élhetett a XIII. század elején, s hogy költő volt, nincs kizárva, de nem bizonyítható” (Márton 1985, 175). Vagyis: „nem létezett”, de „létezhetett”. Feltehetően a XIII. század elején Heinrich von Ofterdingen alakjának számos „költőmodellje” élt és alkotott. 
tanulságait a következőképp foglalja össze: „,a történelmi regény egyik alapvető fikciószabálya, hogy bármennyi képzelt személy szerepeljen is benne, minden egyéb többé-kevésbé meg kell feleljen annak, ami az illető kor való világában történt" (Gyáni 2004, 89).

Mezei Márk regényében tehát Adler Magda az a hős, aki a valóságban nem létezett, de létezhetett (Márton 1985, 175), s akinek sorsa a történelem egy meghatározott korszakát, annak eseményeit „utánképző”4 történeti fikciós próza (pl. történelmi regény) világában „,válságmodell”-ként (Bényei P. 1999a, 443) funkcionálhat.

A narratíva, amelyet a vizsgált regény képvisel, már nagyon messze került azoktól a múfaji konstrukcióktól, amelyeket a hagyományos irodalomtörténet a történelmi regény változataiként határoz meg, s amelyek a múlt reprezentációja során a természetes kronológiai rendnek, illetve ok-okozati viszonyrendszereknek, történelmi ideálképeknek és háttérnarratíváknak való „megfeleltethetöség" (Török 2001, 250) mentén jöttek létre. Az Utolsó szombat azzal is tovább feszíti a müfaj kereteit, hogy a múltra való rálátás szempontja, a múlt értelmezésének módszerei és horizontja az elbeszélésben már nemcsak hogy (a történetírás diszciplínái helyett) szövegalapú tapasztalaton (a másik irodalmi mü világán) alapul, hanem az adott történelmi szerep és személyiség karakterjegyeit is a legendák és a toposzok szolgáltatják számára. Áháron Rokéách belzi rabbi élete alakulásának körülményei Lengyelország, azaz a bochniai gettó elhagyását követően jórészt a szóbeszéd, az urbánus legendák és a képzelet/ következtetések révén rekonstruálhatóak.

Mezei Márk regénye tehát a történeti fikciós prózának abba a sorába illeszkedik, amely a krónikák, történeti munkák mint háttérnarratívák verifikációja helyett valamely „szöveghagyomány része”-ként jelenik meg, „maga válik a referencialitás emlékhelyévé” (Bényei T. 2005, 46): a XXI. század második évtizedében megjelent magyar holokauszt-regények és az általuk képviselt prózahagyomány kontextusában (is) értelmezhető. ${ }^{5}$ Mindennél fontosabb mozzanat, hogy nyilatkozataiban (Hegedüs 2018) maga Mezei is felhívja a figyelmet erre a kontextualizáltságra. Beszédmódja kapcsán Zoltán Gábor Orgia (2016) című regényét említi, előképként pedig Benedek István Gábor Ez lett a vesztünk, mind a kettőnk veszte... (1998) címü filmregényét.

\footnotetext{
4 Az Arany János Széptani jegyzetek címü munkájában (Pap 1934) megjelenő terminust a mai irodalomtudomány is átvette és alkalmazza. Lásd Bényei Péter tanulmányai (Bényei 1999, 1999a).

5 Például Zoltán Gábor: Orgia (2016) és Szomszéd: orgia előtt és után (2018) című művei, Gyurkovics Tamás: Mengele böröndje - Josef M. két halála (2017) címü regényei, meghatározó előképként Kertész Imre és Konrád György regényírása tartozik ide.
} 


\section{Referenciális mozzanatok és legendák Áháron Rokéách regénybeli karakterében}

Az elemzés Mezei Márk Utolsó szombat címü regényének fő motívumait, az elbeszélés folyamatában megjelenő toposzokat értelmezi. Nem módszere a forráskutatás. Épp ezért a belzi rabbi személyét jelölő referenciák értelmezésekor az aktuális recepció által ismert adatokra támaszkodik, ami azért is igazolható eljárás, mert maga a regény(író) is ezekre hagyatkozva formálja meg hősének pszeudo-valóságos ideálképét. A hivatkozott interjúban Mezei a regény központi motívumaként az árulás tényét és mozzanatát jelöli meg:

Nincs olyan történelmi forrás, amelyik ennek az ellenkezőjét állítaná. Tételesen végigmentem az összes elérhető dokumentumon, és nem találtam egyetlen olyat sem, ami ellentmondana ennek. Puhábban, keményebben, de teljesen egyértelmü a történészi megítélés abban a kérdésben, hogy Áháron Rokéách hibázott. Ezt én egy rabbi és szellemi vezető esetében a lehető legszigorúbban bírálom el. Árulásnak tekintem, ezért amikor a könyvről beszélek, az ő megítélésében visszatérően és tudatosan ezt a szót használom, amivel megpróbálom a saját erkölcsi szempontomat kifejezni ebben a kérdésben (Hegedűs 2018).

Áháron Rokéách származásáról, életéről, a lengyelországi gettóból Budapestre történő meneküléséről, ottani tartózkodásáról és távozásáról a rendelkezésünkre álló források olyan megegyező adatokkal szolgálnak, amelyekből rekonstruálhatók cselekedetei és az adott történelmi pillanatban tanúsított magatartása. Homályban maradnak azonban ezeknek mozgatórugói, lelki aspektusai. Ez utóbbiak értelmezésére, azaz a „fehér foltok” - szövegtapasztalatok és archetípusok segítségével történő - kitöltésére vállalkozik a regény írója és elbeszélője; megfejteni azt, mi történt vagy történhetett a nagytiszteletü belzi rabbi lelkivilágában a várakozás és a félelem ideje alatt, amelyeknek hatására - legalábbis a több évtizedes rálátás perspektívájából ítélve - téves döntéseket hozott.

Áháron Rokéách, miként az a vonatkozó feljegyzésekből (Borsányi Schmidt 2006, Deutsch 2008, Raj 2015) kiderül, a legjelentősebb galíciai haszid ${ }^{6}$ rabbidinasztia, a Rokéách család sarja volt, a negyedik belzi rebbe. A Lemberg ${ }^{7}$

\footnotetext{
6 A haszid irodalomról és kultúráról leginkább Martin Buber haszid történetei és annak értelmezései (Rácz 1991, Scholem 1996, Halasi 2014) alapján alkothatunk képet. A magyar irodalom legismertebb haszid meséi Markovits Rodion Reb Áncsli és más avasi zsidókról szóló széphistóriák (Markovits 1939, 2014) címủ novelláskötetében olvashatók.

7 Ma: Lvov, Ukrajna.
} 
mellett elhelyezkedő Belz városka a XVIII. századtól kezdődően ismert haszid vallási központ, a két világháború között különösen sikeres j'sivát ${ }^{8}$ múködtetett (Borsányi Schmidt 2006).

A dinasztiaalapító Sálom Rokéách (1783-1855) rabbi által építtetett, rendeltetésének 1843-ban átadott zsinagóga - a források (Borsányi Schmidt 2006, Deutsch 2008, Anonim 2018) szerint: impozáns és különleges szerkezetü épület sorsa a holokauszt idején pecsételődött meg, végzete beteljesedett, tropológiai értelemben azonban jelentést, szimbolikus értelmet nyert. 1939-ben a náci megszállók először megpróbálták felgyújtani, majd felrobbantani, miután azonban ez nem sikerült, ,arra kötelezték az elfogott zsidó férfiakat, hogy a kezükkel és szerszámokkal bontsák le, tégláról téglára” (Borsányi Schmidt 2006). Már maga a „tégláról téglára” történő „,visszaépítés” folyamata is jelképes értelmü, hangsúlyos toposszá azonban a történet végkifejletében vált, amikor a Palesztinába menekült és ott letelepedett Rokéách fivérek, akiknek minden hozzátartozója és követöiknek legnagyobb hányada a haláltáborokban vesztette életét, hozzálátnak a „belzi” zsinagóga újraépítéséhez és a közösség újrateremtéséhez az új hazában. A bevezetőben említett múltreprezentációs elméletek közül Northrop Frye beszél a világ alakulástörténetének e térbeli toposzok mentén létrejövő ciklikusságáról (Bence 2011, 49-50):

A ciklusnak két fő ritmusa van: az egyén élete és halála s az a lassúbb társadalmi ritmus, amely évek teltével [...] városokat és birodalmakat emel föl és lesújt. Ez utóbbi teljes átlátása az istenek elöjoga. A cselekményt in medias res kezdi, s ezzel a konvencióval mintegy csomót köt az időre. A teljes cselekmény, amely az Iliász hátterét alkotja, a görög városoktól Trója tíz évig tartó ostroma után a görög városokhoz gördül vissza; az Odüsszeia teljes cselekménye ugyanennek specializált példája: Ithakából vissza Ithakába. Aeneis Priamos háziisteneivel vándorol Trójából Új Trójába (Frye 1998, 275).

Áháron Rokéách 1927-ben apját, Rabbi Jisszáchár Dovot (1857-1927) követte a tisztségben. Kezdettől fogva „,csodarabbi”-nak, „cádik”-nak tartották: alakját számos csodatételről szóló legenda övezte. A lengyelországi gettóból való szökésének (1943), majd Budapestről történő távozásának (1944. január $\left.14 .{ }^{9}\right)$ története is ezek, s nem a valós tények fényében vált ismertté. Még a

\footnotetext{
8 Ülés, gyülés. Itt Tóra-tudósokat képző program.

9 A források némi bizonytalanságot mutatnak a távozás pontos időpontját illetően, viszont egyértelműen 1944. január 14-e és január 16-a közé helyezik.
} 
döntéseit és a tetteit vitató, illetve azokat források, ismert adatok tükrében értelmező életrajzírók és emlékezők (Freimovics 1998, Deutsch 2008, Raj 2015) is merítenek legendásított vagy szépirodalmi feldolgozásokból. Alakjának az irreálisba, illetve a transzcendensbe való átcsúszását magyar nyelvterületen nagyban elősegítette egy másik legenda, az Ujszászy István (1894-1948?) tábornok és Karády Katalin (1910-1990) színésznő kapcsolatáról szóló történet, amelynek irodalmi változatát tárja elénk Benedek István Gábor említett filmregénye (Benedek 1998).

A tábornok Áháron Rokéách és fivére, Mordecháj Rokéách megmentésében és megmenekülésében betöltött szerepéröl több forrás is említést tesz, $\mathrm{s}$ ebben a közmegegyezéses ideálképnek megfelelö, azaz a legenda fenntartotta történet interpretálódik:

Lengyelország kettéosztása után - kicsit kihasználva a tisztázatlan helyzetet -, Horthy Miklós személyes titkosszolgálata, Ujszászy István tábornok irányításával Budapestre szöktette a lengyel zsidóság szellemi vezéreit, Rokéách belzi rabbit, és ôt Románián, Törökországon át sikerült az angol fennhatóságú Jeruzsálembe vinni (Zoltai 2006).

A több nyelven beszélő, rendkívüli intelligenciájú tábornok, aki ekkor a katonai hírszerzés vezetője volt, Horthy kormányzó elé tárta a rebbe megmentésének ügyét, s egyben felhívta az államfö figyelmét arra, hogy az akció sikere előnyösen befolyásolná az ország háborúvesztés utáni megítélését. Újszászy tábornok a kormányzó jóváhagyásával, Bethlen és Kállay miniszterelnök utasítására munkához látott. Ennek eredményeképpen Benedek István Gábor regényébe illő körülmények és kalandok között Magyarországra érkezett a rebbe. Budapesti tartózkodása során az orthodox hitközség Kertész u. 32. szám alatti házában lakott, ahonnan csak nagyon ritkán, föleg mikve (rituális fürdő)-használat miatt távozott el (Borsányi Schmidt 1998).

Írásában Borsányi Schmidt Ferenc (Borsányi Schmidt 2006) a Lengyelországból történő menekülés csodás momentumait is részletezi. A visszaemlékezés szerint a különböző lengyelországi gettókban bujkáló Áháron Rokéách épp emiatt, „csodatévő rebbe, vagyis a Belzi Cáddik” mivolta miatt került a Gestapo körözési listájának élére.

A menekültek folyamatosan tudósítottak arról, hogy érzékelték és tapasztalták a „csodákat” menekülésük minden pillanatában. A 250 mérföldnyi úton át a megszállt Lengyelországon - a magyar segítő szerint - a mene- 
küléshez használt jármüvet félelmetes köd vette körül, ami megnehezítette az autó felkutatását. Amikor a magyar segítő arra kérte a gépkocsi vezetőjét, hogy álljon meg út közben és egyenek valamit, s eközben örizetlenül hagyták az autót, még a visszatérők is a sürü ködben, csak nagyon nehezen találták meg kocsijukat (Borsányi Schmidt 2006).

A menekülés története a késő barokk irodalomból ismert név- és ruhacsere (Toldi 2008, 150, Bence 2012, 69), illetve az át- és beöltözés „rituáléjá”-nak (Bence 2018, 41-42) mozzanatait is tartalmazza. Amikor a rabbi titokban elhagyja a bochniai gettó területét, hogy a tőle tanácsot és útmutatást váró követők riadalma ne hívja fel eltủnésére idő előtt a hatóságok figyelmét, egyik tanítványa veszi át imaszobájában helyét és szerepét; a hangját is utánozza (Borsányi Schmidt 2006, Deutsch 2008). A két rabbit, eltüntetve vallási hovatartozásuk, azaz haszid zsidó mivoltuk külső jeleit (ami a pajesz és a szakáll), segítőik elfogott szovjet tiszteknek álcázva őket szállítják Budapestre ${ }^{10}$, de még így is majdnem lebuknak. Hogy ez nem történt meg, hívei a rabbi csodatévő erejével, míg mások konspirációs ügyekkel magyarázzák. Borsányi Schmidtnél olvashatjuk:

Amint a menekülők Magyarország területére értek, több helyen igazoltatták öket. Az egyik ilyen alkalommal személyazonosságuk kétségesnek tetszett, és éppen őrizetbe akarták őket venni, amikor három magas rangú magyar tisztségviselö jelent meg ugyancsak magas rangú magyar tisztek kíséretében, akiknek parancsára az őrjárat a gépkocsi továbbhaladását engedélyezte. A belzi hászidok meggyőződése szerint az első három embert „,a belzi rebbe az égből hívta le”, hogy segítsék mesterük sikeres menekülését. A kevésbé vallásos meggyőződésü, az akkori magyar belpolitikában járatos hírmagyarázók szerint Újszászy tábornok és a hadügyminisztérium illetékesei - esetleg a belügyminisztérium néhány főtisztviselőjével - karöltve siettek a rebbe segítségére (Borsányi Schmidt 2006).

Az identitáscsere, valamint a másnak való beöltözés rituáléja nemcsak a valóságban, de a Mezei-regényben is fontos, jelentésalkotó mozzanattá válik, $\mathrm{s}$ a rabbi másodszori, végleges szökése alkalmával megismétlődik. A folyamat aprólékos leírása a beteljesedés hatásos pillanatait rögzíti: arcszőrzetének eltá-

${ }^{10}$ „A rebbe és testvére az útra leborotválta árulkodó szakállát és pájeszát. Álruhát öltöttek: elfogott orosz tábornokoknak maszkírozták magukat, akik a fronton estek fogságba és Budapestre viszik őket vallomást tenni” (Borsányi Schmidt 2006). „A belzi rabbi leborotválta a szakállát, és orosz, mások szerint lengyel tábornoki ruhában jött át a határon" (Deutsch 2008). 
volíttatása ugyanis hitvallásának, az önmagával (a testi-lelki gyengeségekkel) folytatott küzdelmének feladását, vereségének beismerését mutatja. Áháron Rokéách mindeddig megpróbál szembenézni velük és ellenállni testi kényszereinek, vágyainak, félelmeinek, amiről - a regény világában - az elbeszélői szövegtől tipográfiailag is elkülönülő belső monológok árulkodnak. A valóságban erről utolsó, vitatott értelmü ${ }^{11}$ tanítása, a fivére, Mordecháj Rokéách által kiadott huszonhat oldalas pamflet tanúskodik.

Raj Ferenc is említi cikkében (Raj 2015), miszerint Áháron Rokéáchot az általa elutasított cionista mozgalom tagjai menekítették ki Budapestről, és szállították az angol érdekeltségü Palesztinába. Ellenérzései Mezei Márk regényében is tematizálódnak ${ }^{12}$, illetve az ominózus borotválkozási jelenetben tükröződnek:

${ }^{11}$ „(A Tóra tanítja) 'És látta a nyugalmat'. A cádik látja, hogy nyugalom és békesség (menuchá vesálvá) lesz itt az ország lakói számára. (Az Írás mondja) ’hogy az jó; bizony a cádik látja, hogy jó, minden jó, és csak jó és jóindulat fogja követni és elérni zsidó testvéreinket, akik ezen országnak lakosai...” Dr. Raj Ferenc (a Bét Orim Reform Zsidó Hitközség alapító rabbija, a kaliforniai Berkeley Beth El Közösségének emeritus rabbija) szerint Áháron Rokéách ezzel ahelyett, hogy figyelmeztette volna őket a közelgő vészre - félrevezette híveit (Raj 2015). Más vélekedések (Freimovics 1998) szerint a rabbi „vonakodott” elhagyni Budapestet, de a titkos zsidó ellenállási „,szervezet” tagjai úgy döntöttek, mennie kell. A rabbi így is csak négy börtönbe vetett ellenálló kimenekítése után volt hajlandó rászánni magát e lépésre:

Az akkor még „biztonságosnak” számító Budapesten az foglalkoztatta a rebbét, hogyan lehetne kihasználni minden alkalmat és lehetőséget Lengyelországból Magyarországra átszökött, átcsempészett zsidók megmentésére. Rengeteg pénzbe került egy-egy lélek megmentése. És ki fizetett? Azok a zsidók, akik nem bírták elviselni, hogy testvéreik ezrei nek ontsák a vérét. És ki gyüjtötte össze ezeket a csillagászati összegeket?

A „szervezet” vezetősége négy bátor zsidóból állt. Ök teremtették elő a pénzt sok száz ember átszöktetésére, és igen bőkezüek voltak, amikor Áron Rokéách rabbi és testvére, Mordecháj kerültek sorra.

A kiterjedt hálózat munkájának híre azonban eljutott a németek által terrorizált magyar kormány fülébe is. Több szervezőt és csempészt letartóztattak, köztük a szervezet négy vezetőjét. Ekkor úgy határoztak, hogy beszüntetik tevékenységüket.

A rebbét mély aggodalom töltötte el, amikor hírt kapott a letartoztatásokról. A pesti zsidóság latba vetette minden létező befolyását. Magas személyiségeket próbáltak elérni, de minden erőfeszítésük hiábavaló volt.

A rebbe tisztában volt azzal, hogy őt magát is letartoztatás fenyegeti. Ennek ellenére azt mondta: „Nem mozdulok Budapestről, amíg az a négy ember, aki szívét-lelkét áldozta a zsidó nép megmentéséért, börtönben sínylődik" (Freimovics 1998).

12 „Megpróbált erőt meríteni abból az érzésből, hogy mennyire utálja a neológ zsidókat. Kerüli a társaságukat” (Mezei 2018, 81). Vagy: „Akárhogy tiltották a cionista és neológ vezetők, a lakás a galíciai zsidók rendszeres találkozóhelyévé vált. A belzi hívek tántoríthatatlanok voltak, a héderekben tanuló gyerekektől a kolelokban éjszakázó öregekig mindenki a rebbéje közelében akart lenni” (Mezei 2018, 165). 
A rabbi egy darabig a fejét lehorgasztva töprengett, mint aki az utolsó pillanatban meg akarná gondolni magát, de végül nem szólalt meg, csak felemelte tekintetét, és a legöregebbre nézve biccentett. Ez adta meg a jelet ahhoz, hogy hozzákezdhetnek. Az öreg először a szakálla nagyját vágta le az ollóval, majd a megnedvesített szappannal dörzsölte be a rabbi arcát, aki, ha viszolygott is attól, hogy ismeretlenek érjenek hozzá, megadóan türte az egészet. Miközben az öreg borotválta, a legifjabb egy szökéshez szükséges katonai egyenruhát terített ki az ágyra (Mezei 2018, 244-245).

Bizonyos szegmenseiben a narratíva egészen közel kerül forrásaihoz, szinte szó szerint idézi azokat:

A hatóságok az érkezésük első pillanatától tudták, merre bujkálnak, és ebből nem is csináltak titkot. Egy Haink nevű rendőr a külföldieket ellenőrző osztályra is berendelte őket, hogy elmondja, a regnáló magyar kormány nem lesz képes sokáig ellenállni a németek nyomásának, előbbutóbb ki kell adniuk az elfogatóparancsot. Ahogy fogalmazott, javasolnám, hogy mihamarabb hagyják el Magyarországot, néhány napot talán még mi is várhatunk a végrehajtással (Mezei 2018, 31).

De Budapesten számukra a rettegés napjai következtek. Hain Péter, a rendőrség vezetője berendelte őket a külföldieket ellenőrző osztályára (KEOKH). A kettőjük között lezajlott fél órás beszélgetés során a rendőrfőkapitány németül közölte vele: „A németek nyomást gyakorolnak a magyar kormányra, hogy tartoztassuk le Önt, aki engedély nélkül hagyott el egy a nácik által meghódított területet... Hosszú ideig képtelenség visszatartani a parancs kiadását. Javasolnám, hogy mihamarabb hagyja el Magyarországot, addig talán várhatunk a végrehajttatással" (Freimovics 1998).

Referenciális vonatkozások közvetve, az álmok, a látomások és metaforikus érzékelések szintjén is megjelennek az elbeszélésben. Amikor a rabbi kora reggel - a vallási elöírásoknak megfelelően - megmártózik a jeges folyóban, aminek funkciója és jelentése ${ }^{13}$ eredeti értelmében és az adott pillanatban is a „megtisztulás” rituáléja lett volna, váratlanul eszméletét veszti, és az eljövendő holokauszt képei jelennek meg elötte:

\footnotetext{
${ }^{13}$ A feltehetően a szent iratokból idézett szöveg Mezei regényében is kiemelt, tipográfiailag is elkülönülő: , Az első férfi is egy folyóban mártotta meg magát a paradicsomból való kiüzetése után. Azzal akart visszatérni az eredeti tökéletesség állapotába” (Mezei 2018, 98).
} 
Tisztán kivehető arcokkal telt meg a sötét folyam. Akárhova nézett, csapkodó karokat, segélykiáltásra nyílt szájakat, bugyborékoló, megfeszülő testeket látott. Megcsonkolt végtagokat. Kiugró pofacsontokkal keretezett, hosszú arcú nőket. Bozontos öleket. Szétzilált hajfonatokat. Mellek és vállak világos foltjait. Kisírt szemü, felzaklatott, kétségbeesett, gyermekeiket visszakövetelö, reménykedő anyákat. Egykori közössége nőtagjai örvénylettek körülötte (Mezei 2018, 100).

Hasonló funkciót tölt be a regény „fehér galamb”-szimbólumra épülő fejezete; a legerőteljesebben metaforizált rész. A lepusztult bérház udvarán, ahol Áháron Rokéách és a kitalált hős, Adler Magda is rejtőzködik, egy csapat elvadult galamb közé száll le egy idegen, szemmel láthatóan tenyésztett, nemes, szép madár, amelyet büzös és barátságtalan társai tizenhárom csípéssel ölnek meg. A regényhős, vagyis a rabbi nem, de a befogadó, aki korábban már olvasta és ennek nyomán „látta”, elképzelte a jelenetet, tudja, hogy ezt a döglött galambot lépi át az utolsó budapesti sábeszre tartva, amikor magát árulóvá aposztrofálva, szökésre elszántan, már „tudta, milyen beszédet akar mondani” (Mezei 2018, 195).

Adler Magda a szó klasszikus értelmében nem kitalált hős, csak úgy, amiképp az általunk idézett Frye-elmélet (Frye 1998, 263), illetve Márton László ${ }^{14}$ szintúgy hivatkozott értelmezése szól a „nem létezo”, de „létezhetett” pszeudovalóságos szereplőről. A rabbi sorsával párhuzamosan gördülö élete és hánykódása annak visszképét, paradoxonát mutatja meg. Magda pontosan azt a, még csak neológnak sem mondható, asszimiláns zsidótípust testesíti meg, akitől a rabbi megvetéssel távolodik el:

Émelyítő csömört érez álnokságuk, tanulatlanságuk, állandó kelletlenségük miatt. Ahogy hallgatnak. Ahogy kétértelmüen mosolyognak. Járatlanok a Talmudban, és nem a dereh eretz szerint élnek. Szinte fizikai rosszullét fogta el önelégült, cinkos arcuktól. Sötét kacsintásaiktól. Fennhéjazó viselkedésüktől. Hogy csak az foglalkoztatja őket, hogyan járhatnak a legjobban. Magyarnak kellene lenem, ha meg akarnám öket érteni (Mezei 2018, 81).

Testi-lelki vívódása és kiszolgáltatottsága (nemi vágyai, bünös érzelmei, félelmei) ellen folytatott, kudarccal végződő küzdelme során a rabbi mind közelebb kerül az általa elutasított magatartáshoz, világértéshez és életvezetési mintához: „Nem volt már rabbi vagy talmud tudós, csak egy életéért reszkető

14 Vö. 2. 
gyáva alak. Látta magában azt a hideg és érzéketlen embert, akitől egész életében menekült" (Mezei 2018, 189).

Adler Magda valóban távol áll minden, a korra jellemző társadalmi eszménytől; nincs köze a héber kultúrához, miként a zsidó vallás egyetlen irányzatához sem. Saját bevallása szerint nem tud zsidó módra imádkozni akkor sem, ha szükségét érzi, s a kor elöítéleteit elfogadva, a jiddist „rontott német”-nek tekinti. Alkoholista, biszexuális, valamiféle furcsa, „lelki szado-mazo” irányultsággal rendelkezik, lévén arról szó, hogy kiszolgáltatja magát egyrészt Zsigmond, egy náci ideológiákkal szimpatizáló férfi megalázó szexuális közeledéseinek és vágyainak, másrészt aberrált érzéketlenséggel és gonoszsággal gyötri Krisztinát, vidéki, egyszerü keresztény cselédjét és szeretőjét. Bizonyos értelemben a fordítottját járja be a rabbi útjának: a vészkorszakban egyre erőteljesebben szembesül megtagadott zsidó identitásával: „Zsidó. Nem tudta, honnan jutott most megint eszébe ez a szó, de szinte azonnal földre rántotta. Büdös zsidó. Ilyennek képzelte azokat a pillanatokat, amikor egy végtelenül kicsi dolog dönt el örökre egy valami nagyot az életben. Örökre bünös lettél' (Mezei 2018, 219).

Megegyező vonása sorsuknak, hogy mindkettejüknek olyan szellemi feladatot jelöl ki végzetük, amelyet testi hiányosságaik és devianciáik miatt képtelenek teljesíteni. Áháron Rokéáchot cádiknak tekintik hívei, akinek jelenléte útmutatást és biztonságot kellene jelentsen számukra. Ennek a predesztináltságnak azonban képtelen megfelelni, amit - mintegy bizonyítékul - fennmaradt utolsó budapesti beszéde is alátámaszt, amelyben - ahelyett, hogy menekülésre szólítaná fel öket - megnyugtatja (,,a cádik látja, hogy nyugalom és békesség [menuchá vesálvá] lesz itt az ország lakói számára" [Raj 2015]), és ezzel félrevezeti hittársait, akiknek többsége a két hónap múlva bekövetkező német megszállás során haláltáborokban végezte, miként a rabbi és fivére Lengyelországban maradt minden családtagja; Áháron Rokéáchnak felesége, hét gyermeke és huszonhat unokája.

Adler Magda, noha ilyen nevű személyt nem tart nyilván a történeti emlékezet, nem kitalált személy, hanem csak egyike azoknak a névtelen kisembereknek, akik akár passzív, akár aktív módon, akár tudatos ellenállóként, akár véletlenül sodródva a kommunista ellenállási mozgalomba (mint Magda), de áldozatául estek a másik ember identitására törő bosszúvágynak, türelmetlenségnek és intoleranciának. Krisztina, a szeretője jelenti fel. Feltehetően ez sohasem történt így meg, de bárhol és bármikor megtörténhetett.

A rabbi és a kommunista ellenálló (a cádik és az asszimiláns) sohasem találkoznak életükben, egy pillanatra ugyanakkor keresztezi egymást sorsuk: épp abban a pillanatban, amikor a menekülő, álruhás rabbival elindul a gépkocsi, 
„a városra vetett egyik utolsó tekintete elé [...] az a kép úszik be, amikor a rajtaütés során életét vesztett Magda lecsüngő kezü testét kihozzák az épületből. Ha a rabbi menekülését a hívei cserbenhagyásának, árulásnak fogjuk fel, akkor ez az utolsó kép emblematikus értelmet nyer: elörevetíti Rokéách számára tette majdani következményeit" (Bence 2019, 108-109). Szimbolikus jelentése mellett e jelenetben a fikció és a valóság találkozik ismét, hiszen több forrás is jegyzi, hogy a rabbi távozását követően az államvédelmi egységek hatalmas razziát tartottak Budapesten (Borsányi Schmidt 1998, Freimovics 1998, Deutsch 2008, Pelle 2014, Raj 2015).

\section{Összegzés}

Idézett interjújában (Hegedús 2018) Mezei Márk egyértelmủen kijelenti: tételesen megvizsgálva a rendelkezésre álló dokumentumokat, arra a megállapításra jutott, hogy a források többé-kevésbé egyetértenek abban, Áháron Rokéách hibázott, amikor 1944 januárjában nem figyelmeztette a benne csodatevőt látó híveit, s ezáltal lelkiismeretlenül kiszolgáltatta őket a megszállók kénye-kedvének. Vagyis áruló lett, amit Mezei egyértelmüen tematizál regényében, fokozva jelentőségét úgy, hogy a konzekvenciát maga a főhős, a pszeudo-valóságos alakmás vonja le a róla szóló regényben: „Hazug lettem. Na és? Semmi sem számit már. Ebben a helyzetben a tisztesség értelmezhetetlen. Nincs miért vagy kiért helytálljak. Csak önmagamért felelek. A túlélés az egyetlen kötelességem. Aki megmenekül, tanithat. Gyereket nemzhet. Aki viszont már a sárban fekszik, az csak a feltámadásban reménykedhet" (Mezei 2018, 170). Arról, hogy az Utolsó szombat az árulás jelenségét történeti referenciákra vetítve tematizáló regény, konszenzusos véleményt alkot a kritika (Balázs 2018, Bence 2019, Fináli 2018, Hegedüs 2018).

Egyes cikkírók (Freimovics 1998, Deutsch 2008) Áháron Rokéách mentségét (nyilvánvalóan ezek voltak Mezei forrásai is) ugyanazon momentumokban látják igazolhatónak, mint amire a regényhős hivatkozik: Szentföldön újrateremtheti a belzi zsidó közösséget:

Kinek lehet igaza? Talán senkinek, talán mindenkinek. Aki bujdosik, annak változtatnia kell a búvóhelyét, mégpedig gyakran. Egy szombat délután Sálé Szüdeszt - harmadik lakomát - adott a Hitközség dísztermében, ahol megáldotta a várost, amely neki menedéket nyújtott. A zsidóságból, akik, ha megtudták, merre jár, arra sétáltak, várakoztak akár órákig, hogy egy-két percig láthassák a legendás mestert. Igen sokan állítják, azért menekült meg a pesti gettó a teljes likvidálástól, mert 
védte a jámbor lélek áldása. Mások azt mondják, hogyan hagyhatta el a családját, a közösségét a vezér, hiszen a kapitány utolsónak hagyhatja el a süllyedő hajót, és nem az elsők között. A válasz: a kílé, a közösség határozott úgy, hogy menjen a bölcs, és híres iskoláját müködtesse a Szentföldön. De megőrizve a belzi nevet! (Deutsch 2008).

A fenti érvek egybecsengenek Northrop Frye-nek a bevezetőben idézett, a történelem alakulásának ciklikusságáról alkotott véleményével: az Új Haza/ Új Trója létrehozásának eposzi szellemiségü történelemértelmezésével. Sajátos módon, a Rokéách-történetben is referenciákra fordítható mozzanat. Áháron Rokéáchnak, noha kétszer is újranősült Palesztinában, nem született utóda, ugyanakkor Mordecháj fivére 1950-ben bekövetkezett halála után felnevelte és Tóra-tudóssá képezte unokaöccsét, Dov Rokéáchot (1948), a jelenlegi, azaz az ötödik belzi rabbit, aki 1980-ban tette le Jeruzsálem területén az új belzi zsinagóga alapköveit.

Hasonlóan az eredeti zsinagógához Belzben, amelynek építése, befejezése 15 esztendőt vett igénybe, az új Béit há-Midrás há-Gádol (az új Nagy Zsinagóga), ami uralkodik az egész Észak-Jeruzsálem égboltján, ugyancsak 15 évig épült; 2000-ben avatták. Belső terének központi része 6000 imádkozó számára ad ülőhelyet. A hatalmas Áron há-Kodes (Tóraszekrény, Frigyszekrény) több mint 100 tóratekercset tartalmaz. A fözsinagóga kilenc csillárja összesen 200000 cseh kristályból készült. Úgy hitték, a zsinagógát Belzben és használóit 1944-ben a gyülölet megsemmisítette. A belzi szellem, az Örökkévaló szolgálatának Belzben kialakult módja és liturgiája Izraelben és máshol tovább él, és az Erecben felépült zsinagógájukban minden imaidőben több ezer ifjú és idősebb hászid imádkozik a Belzben született dallamokra (Borsányi Schmidt 1998).

\section{Irodalom}

Anonim. 2018. Éjszaka a zsinagógában. Cultura. Kulturális magazin. 2018. jún. 19. https://cultura.hu/kultura-plusz/ejszaka-a-zsinagogaban/ (2019. aug. 18.)

Balázs András. A holokauszt árnyékában - Mezei Márk Utolsó szombat címü regényéröl. 168 óra. 2018. júl. 25. https://168ora.hu/kultura/a-holokauszt-arnyekabanmezei-mark-utolso-szombat-cimu-regenyerol-153471 (2019. máj. 2.)

Barthes, Roland. 1997. S/Z. Ford. Mahler Zoltán. Budapest: Osiris.

Bence Erika. 2011. A múlt horizontja: A történelmi regény müfaji változatai a XIX. századi magyar irodalomban. Újvidék: Forum. 
Bence Erika. 2012. Barokk kor, barokk idő: új magyar „barokk” regény. Márton László: Testvériség I-III. In Uö: Arachné szőnyege: A magyar irodalom alakulástörténeti „, szövevénye” a XVIII. század végétöl napjainkig. 63-71. Újvidék: BTK-VMFK.

Bence Erika. 2018. Rituali kulturnog preoblačenja u romanu Neoplanta ili Obećana zemlja Lasla Vegela. In Drugost: Zbornik radova sa Međunarodne naučne konferencije o književnom delu Lasla Vegela, održane 24. i 25. maja 2018. godine u Novom Sadu. Tekstove sa mađarskog jezika preveli: Arpad Vicko i Marta Palić. 41-57. Novi Sad: Akademska knjiga.

Bence Erika. 2019. Az árulás testi kényszere. Mezei Márk: Utolsó szombat. Bárka 26 (3): 108-111.

Benedek István Gábor. 1998. Ez lett a vesztünk, mind a kettőnk veszte... Budapest: Magyar Könyvklub.

Bényei Péter. 1999. A történelmi regény müfajkonstituáló tényezőinek meghatározási kísérlete. Studia Litteraria 37. 55-89.

Bényei Péter. 1999a. „El volt tévesztve egész életünk”. Esztétikai alapú létértelmezési kísérlet a történelmi regény müfaji konzekvenciái alapján. Kemény Zsigmond: A rajongók. Irodalomtörténet 30 (3): 441-465.

Bényei Tamás. 2005. Történelem és emlékezés a kortárs történelmi regényben. Alföld, 56 (3): $37-47$.

Borsányi Schmidt Ferenc. 1998. A rébe, a tábornok és Budapest. Zsido.com. http:// zsido.com/fejezetek/a-rebbe-a-tabornok-es-budapest/ (2019. aug. 18.)

Borsányi Schmidt Ferenc. 2006. A belezi hászidok és híres rebbéik. Remény 22 (2): http://www.remeny.org/remeny/2006-nyara-5766-tamuz-av-elul/borsanyi-schmidtferenc-a belzi-haszidok-es-hires-rebbeik/ (2019. febr. 10.)

Deutsch Gábor. 2008. Belz, az én kis városkám. Remény 24 (3): http://www.remeny. org/remeny/2008-tel/deutsch-gabor-belz-az-en-kis-varoskam (2019. febr. 10.)

Fináli Gábor. 2018. Mezei Márk regénye a bálványrombolással marad hüséges a zsidósághoz. KönyvesBlog (2018. szept. 4.) https://konyves.blog.hu/2018/09/04/ mezei_mark_regenye_a_balvanyrombolassal_marad_huseges_a_zsidosaghoz (2019. febr. 10.)

Freimovics, Chájim. [1996] 1998. Miért vonakodott elhagyni Magyarországot 1943 ban Reb Áron Rokéách, a belzi csodarabbi? (Bámáchne Háchárédi, Jerusalem, 1996.) Egység 33 (3): http://zsido.com/fejezetek/miert-vonakodott-elhagynimagyarorszagot-1943-ban-reb-aron-rokeach-a-belzi-csodarabbi/ (2019. febr. 10.)

Frye, Northrop. 1998. A kritika anatómiája. Ford. Szili József. Budapest: Helikon.

Gyáni Gábor. 2004. Történelem és regény: a történelmi regény. Tiszatáj 58 (4): 78-93.

Gyurkovics Tamás. 2017. Mengele böröndje: Josef M. két halála. Budapest: Kalligram.

Halasi Zoltán. 2014. Isten megélhetése - Martin Buber: Haszid történetek. http://www. atlantiszkiado.hu/pdf/mancs_06_09_14.pdf (2018. máj. 30.) 
Hcl. [Hegedüs Claudia]. 2018. Csendbörtönök. Olvass bele! A kultúrkirakat (2018. aug. 28.) https://olvassbele.com/2018/08/28/csendbortonok-mezei-mark-utolsoszombat/ (2019. máj. 2.)

Hegedüs Claudia. 2018. Döntő történelmi pillanatban hallgatni ugyanolyan fontos cselekedet, mint megszólalni. KönyvesBlog (2018. aug. 24.) https://konyves.blog. hu/2018/08/24/donto_tortenelmi_pillanatban_hallgatni_ugyanolyan_fontos_cselekedet_mint_megszolalni\#more14197119 (2019. máj. 2.)

Lukács György. 1977. A történelmi regény. Budapest: Magvető.

Markiewicz, Henryk. 1968. Az irodalomtudomány fó kérdései. Ford. Bojtár Endre. Budapest: Gondolat.

Markovits Rodion. [1939] 2014. Reb Áncsli és más avasi zsidókról szóló széphistóriák. Reb Ancili şi alte povestioare despre evreimea oaşului. In Schiller Erzsébet: Kisgércétől a világhírig és vissza. 6-11. Ford. Felician Pop. Prefeță. 7-12. KolozsvárCluj-Napoca: Kriterion Könyvkiadó-Editura Kriterion.

Márton László. 1985. Magyarázatok, jegyzetek és életrajzi adatok. Novalis: Heinrich von Ofterdingen. 173-195. Budapest: Helikon.

Mezei Márk. 2018. Utolsó szombat: Regény. Budapest: Kalligram.

Pap Károly szerk. 1934. Bevezetö. Arany János-emlékkönyv II. Arany János Széptani jegyzetei: A költő halálának félszázados évfordulója alkalmából. 1-27. Budapest: MTA.

Pelle János. 2014. Az „idegen zsidók” és a m. k. Belügyminisztérium. Valóság: 57 (6): 34-48. http://epa.oszk.hu/02900/02924/00018/pdf/EPA02924_valosag_2014_6_ 034-048.pdf (2019. aug. 3.)

Rácz Péter. 1991. A haszidok világa. Pompeji 2 (1): 8-14.

Raj Ferenc. 2015. Belz, Budapest, Jeruzsálem: egy megmenekülés árnyoldala. Szombat: Zsidó kulturális és politikai folyóirat 27 (2). https://www.szombat.org/tortenelem/ belz-budapest-jeruzsalem-egy-megmenekules-arnyoldala (2019. febr. 10.)

Scholem, Gershom. [1963] 1996. Martin Buber haszidizmus-értelmezése. Ford. Rácz Péter. Holmi 9. 1351-1364. http://epa.oszk.hu/01000/01050/00149/pdf/EPA01050 holmi_1996-09_1351-1364.pdf(2018. máj. 30.)

Toldi Éva. 2008. A múltreprezentáció lehetőségei. Újvidék: Forum.

Török Lajos. 2001. A történelem félreolvasása. Jókai Mór: Erdély aranykora. In SzegedyMaszák Mihály-Hajdu Péter szerk. Romantika: világkép, müvészet, irodalom. 242-259. Budapest: Osiris.

Zoltai Gusztáv. 2006. Tisztelgés Henryk Slawik előtt. Remény 1. http://www.remeny. org/remeny/2006-tavasz-5766-adar-niszan-ijjar/zoltai-gusztavtisztelges-henrykslawik-elott/ (2019. aug. 18.)

Zoltán Gábor. 2016. Orgia. Budapest: Kalligram. 


\section{REFERENTIAL AND FICTIONAL FEATURES IN MÁRK MEZEI'S NOVEL UTOLSÓ SZOMBAT (THE LAST SATURDAY)}

The plot of the novel The Last Saturday (Utolsó szombat) by Márk Mezei is set in a real space and time, in a rather narrow framework: $14^{\text {th }}$ January 1944, in a dilapidated apartment building in Budapest, 32 Nagyatádi Szabó Street. One protagonist, Aaron Rokeach, the Rebbe of Belz, is a historical character: his life references are known. The other protagonist, Magda, is a fictional character and - contrary to the Jewish Orthodox leader - she comes from an assimilate family, she is ignorant of the traditions of her religion, she is bisexual and an alcoholic. They both fall into a state of extreme loneliness generated by fear of being caught and destroyed: the Rebbe becomes a traitor leaving his community and brothers by faith, while Magda becomes a victim of love betrayal. They come into an identical life situation, only a few meters apart: nevertheless, the sense of fear erects an impenetrable wall between them. They never meet. This paper examines the motivic and tropological features of the narrative.

Keywords: fictional, referential, body, soul, motifs, tropes

\section{REFERENCIJALNO I FIKTIVNO U ROMANU MARKA MEZEIJA UTOLSÓ SZOMBAT (POSLEDNJA SUBOTA)}

Radnja romana Utolsó szombat (Poslednja subota) Marka Mezeija odigrava se u stvarnom prostoru i vremenu, u prilično uskim okvirima: 14. januara 1944, u propaloj stambenoj zgradi u Budimpešti, u ulici Nađatadi Sabo broj 32. Jedan od protagonista, Aron Rokeah, rabin iz dinastije Belz, istorijska je ličnost: poznati su referencijalni aspekti njegovog života. Drugi glavni lik, Magda, fiktivna je ličnost i - nasuprot jevrejskom ortodoksnom duhovnom vođi - potiče iz porodice gde je asimilacija već završena, ne poznaje tradiciju svoje vere, biseksualna je i alkoholičarka. Oboje upadaju u ekstremnu samoću izazvanu strahom od pada i propasti: rabin postaje izdajnik ostavivši svoju zajednicu i braću po veri, dok Magda postaje žrtva ljubavne izdaje. Dolaze u jednaku životnu situaciju, udaljeni su svega nekoliko metara: ipak, osećaj straha diže nepremostiv zid među njima. Nikada se ne susreću. Rad se bavi motivima i tropima narativa.

Ključne reči: fiktivno, referencijalno, telo, duša, motivi, tropi 